http://jmscr.igmpublication.org/home/ ISSN (e)-2347-176x ISSN (p) 2455-0450 crossref DOI: https://dx.doi.org/10.18535/jmscr/v7i11.35

\title{
A Rare Presentation of Migraine
}

Authors

\section{Uthaya Sankar M.K' ${ }^{1}$, Louis Ferdin Zeno.J ${ }^{2}$, Mythreini Satheesh ${ }^{3}$}

${ }^{1}$ Professor, ${ }^{2,3}$ Post Graduate Residents, Department of General Medicine, Sri Manakula Vinayagar Medical College and Hospital, Puducherry-605107, India

Abstract
Familial hemiplegic migraine (FHM) is a rare subtype of migraine with prevalence of $0.003 \%$. Here we
report a case presented with headache with nausea and blurring of vision with associated limb weakness
with similar episodes in the past and a positive family history with a normal neuroimaging.

\section{Introduction}

Familial hemiplegic migraine (FHM) is a rare subtype of migraine presenting with recurrent attacks of migraine with aura and transient neurological deficit ${ }^{1}$. The prevalence of FHM is $0.003 \%$. It is of four types. As of now three genetic mutations are identified-CACNA1A gene in FHM1, ATP1A2 gene in FHM2 and SCN1A gene in FHM3. These genetic mutations cause abnormalities in the ion channels, altering the membrane excitability and predisposing to migraine $^{3}$.

\section{Case Report}

A 31 years old male presented with headache, blurring of vision in the left eye, nausea followed by weakness of left upper and lower limb for 6 hours duration. He had similar complaints twice in the past and got resolved within a day. $\mathrm{He}$ also had history of similar complaints in his family with his brother and mother. CNS examination revealed decrease power and tone on left side. His blood investigations were normal. His neuroimaging revealed normal study. $\mathrm{He}$ was diagnosed as Familial hemiplegic migraine. He was treated with calcium channel blocker and advised to follow up. On follow up his symptoms were resolved.

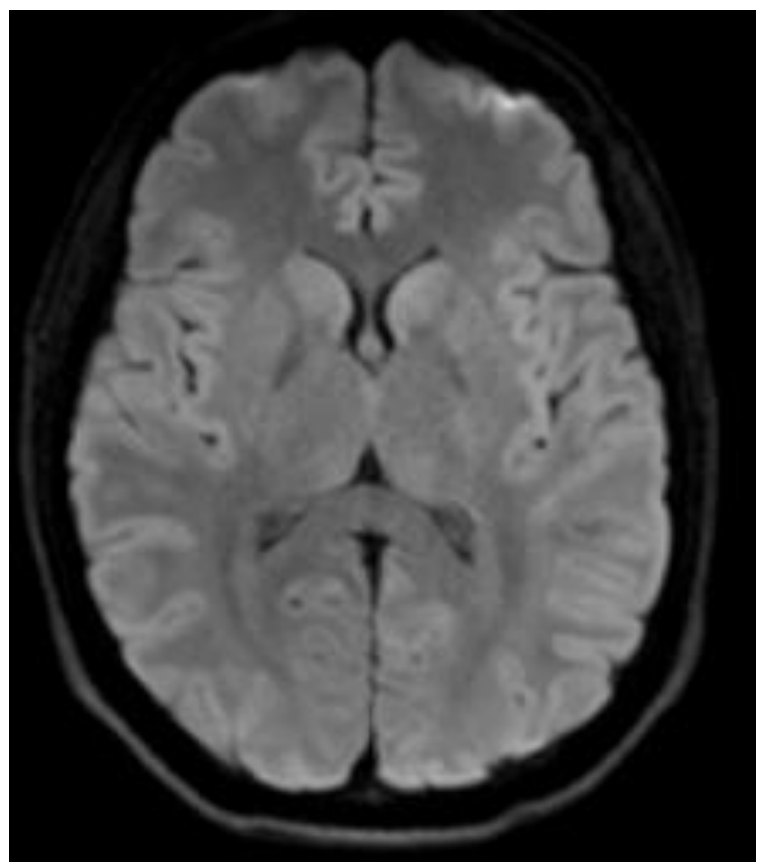

Fig 1: Contrast enhanced MRI brain showing normal brain parenchyma 


\section{Discussion}

Familial hemiplegic migraine is a rare autosomal dominant subtype of migraine with aura. These patients present typically with aura features mostly visual, headache, nausea followed by weakness mostly resolving within a day. Three mutations have been identified. A mutation in CACNA1A, a gene located on chromosome 19 p13 that codes for voltage gated calcium channel and is associated with FHM1. The gene mutation for FHM2 is on chromosome 1q23 in the ATP1A2 gene, a gene that codes for sodium potassium ATPase pump. FHM3 is associated with mutation in the gene SCN1A on chromosome 2q24 which codes for neuronal voltage gated sodium channel ${ }^{3}$. Treatment for FHM is similar to other migraines including pain relief and prophylaxis.

\section{References}

1. Pranav B, Katakam P, Asha P. Familial hemiplegic migraine in a child with seizure disorder. BMJ 2019 Mar;4:1-3.

2. Kumar A, Arora R. Hemiplegic migraine. Stat pearls 2019 Jan:1-4.

3. Kasper DL, Hauser SL, Jameson JL, Fauci AS, Longo DL, Loscalzo J. Harrison's principle of internal medicine. 20th ed. New York: The McGraw-Hill Companies; 2018.p.3096. 